\title{
As mãos não podem salvar o mundo
}

\author{
Joana D'Arc Chaves Campos
}

Lêda Valéria Alves da Silva

Tocar

Ler o futuro

As mãos carregam o destino do mundo?

Agir

Pilatos lavou as mãos

Não salvou Jesus

Então as mãos podem salvar?

Traçar

Caminhos

Atalhos

Destinos

Mas vamos chegar?

Queremos chegar?

Ao mundo ideal?

Ao futuro melhor?

À geração perfeita?

Qual a ação

Perfeita

Ideal

Melhor?

Para que as mãos possam salvar o mundo 
Da tragédia

Da destruição

Das pessoas

Do perigo? Do abismo?

Desse ECO que fala por nós

Dessa vida dita

Silenciada

Apagada

Findada

Pelas mãos...

Que podem não salvar, mas podem inventar outros mundos!!

Joana D'Arc Chaves Campos é Graduada em Licenciatura Integrada em Educação em Ciências, Matemática e Linguagens pela UFPA; bolsista de iniciação científica CNPq; integrante do Grupo de Estudos e Pesquisas sobre Cultura e Subjetividade na Educação em Ciências (GEPECS).

Lêda Valéria Alves da Silva é Graduada em Ciências Biológicas pela UFPA. Atualmente cursa doutorado em Educação em Ciências na mesma universidade. 